\title{
Evaluation on the role of sulfuric acid in the mechanisms of new particle formation for Beijing case
}

\author{
Z. B. Wang ${ }^{1}$, M. Hu ${ }^{1}$, D. L. Yue ${ }^{1}$, J. Zheng ${ }^{2}$, R. Y. Zhang ${ }^{1,2}$, A. Wiedensohler ${ }^{3}$, Z. J. Wu ${ }^{1,3}$, T. Nieminen ${ }^{4}$, and M. Boy ${ }^{4}$ \\ ${ }^{1}$ State Key Joint Laboratory of Environmental Simulation and Pollution Control, College of Environmental Sciences and \\ Engineering, Peking University, Beijing 100871, China \\ ${ }^{2}$ Department of Atmospheric Science, Texas A\&M University, College Station, Texas 77843, USA \\ ${ }^{3}$ Leibniz Institute for Tropospheric Research, Permoserstrasse 15, 04318 Leipzig, Germany \\ ${ }^{4}$ Department of Physics, University of Helsinki, P.O. Box 64, 00014 Helsinki, Finland
}

Received: 8 August 2011 - Published in Atmos. Chem. Phys. Discuss.: 29 August 2011

Revised: 27 October 2011 - Accepted: 16 November 2011 - Published: 15 December 2011

\begin{abstract}
New particle formation (NPF) is considered as an important mechanism for gas-to-particle transformation, and gaseous sulfuric acid is believed as a crucial precursor. Up to now few field-based studies on nucleation mechanisms and the role of sulfuric acid were conducted in China. In this study, simultaneously measurements of particle number size distributions and gaseous sulfuric acid concentrations were performed from July to September in 2008. Totally, 22 new particle formation events were observed during the entire 85 campaign days. The results show that in the case of both higher source and sink values, the result of the competition between source and sink is more likely the key limiting factor to determine the observation of NPF events in Beijing. The concentrations of gaseous sulfuric acid show good correlations with freshly nucleated particles $\left(N_{3-6}\right)$ and formation rates $\left(J_{3}\right.$ and $\left.J_{1.5}\right)$. The power-law relationship between $\mathrm{H}_{2} \mathrm{SO}_{4}$ concentration and $N_{3-6}$ or $J$ is adopted to explore the nucleation mechanism. The exponents are showed a great range (from 1 to 7). More than half of the NPF events exhibit an exponent larger than 2.5. For these cases, the thermodynamic process works better than the activation or kinetic nucleation theories to explain the nucleation events in urban atmosphere of Beijing.
\end{abstract}

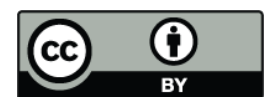

Correspondence to: $\mathrm{M} . \mathrm{Hu}$ (minhu@pku.edu.cn )

\section{Introduction}

New particle formation (NPF) and the subsequent particle growth have been observed in various environments all over the world (Kulmala et al., 2004; Holmes, 2007). Model results suggest that nucleation may be an important source of condensation nucleus $(\mathrm{CN})$ and cloud condensation nuclei $(\mathrm{CCN})$ in global scale (Spracklen et al., 2008; Merikanto et al., 2009). The particle growth could affect the global climate system by scattering and absorption of solar radiation directly (Stier et al., 2007). Furthermore, these particles may act as CCN and ice nuclei (IN) and influence the climate system indirectly (Lohmann and Feichter, 2005). In order to obtain an improved understanding of the various effects of atmospheric particles, the properties of the nucleation and growth should be understood completely and validated for different areas.

Gaseous sulfuric acid has been identified as a key component in the NPF process (Weber et al., 1995; Kulmala, 2003; Berndt et al., 2005; Fiedler et al., 2005) and proposed as a key component in many nucleation theories, such as binary, ternary or ion-induced nucleation (Korhonen et al., 1999; Weber et al., 1999; Yu and Turco, 2000; Napari et al., 2002; Vehkamaki et al., 2002). In order to investigate the role of sulfuric acid in the nucleation process, based on recent observations the relationship between observed nucleation rates and ambient gaseous sulfuric acid concentrations with an exponent between $1\left(J=A \times\left[\mathrm{H}_{2} \mathrm{SO}_{4}\right]\right)$ and 2 $\left(J=K \times\left[\mathrm{H}_{2} \mathrm{SO}_{4}\right]^{2}\right)$ have been reported (Sihto et al., 2006; Riipinen et al., 2007; Boy et al., 2008; Kuang et al., 2008; Nieminen et al., 2009; Paasonen et al., 2009). In these

Published by Copernicus Publications on behalf of the European Geosciences Union. 
publications the authors pointed out that the activation and kinetic nucleation maybe the potential formation mechanisms. Meanwhile, the role of low-volatile organic vapors to atmospheric nucleation caused widespread attentions and several recent studies suggested that organic vapors do participate in the nucleation process (Bonn et al., 2008; Paasonen et al., 2009, 2010; Lauros et al., 2011).

Although the NPF events were observed all over the world, the measurements of gaseous sulfuric acid are rare, especially in urban polluted environment. A few campaigns had been conducted in urban environments only provide the measurements of particle number size distributions (Dunn et al., 2004; Kulmala et al., 2005; Hamed et al., 2007; Smith et al., 2008; Salma et al., 2011). High frequency of NPF event was observed in Beijing based on a one-year statistical analysis (Wu et al., 2007). Yue et al. (2010) pointed out that sulfuric acid plays a dominant role in both the nucleation and subsequent growth processes. Nevertheless, the relationship between sulfuric acid and freshly nucleated particles or formation rates is still unclear.

In this paper, we present the Beijing case for the NPF as an urban polluted atmosphere. Based on simultaneous measurements of particle number size distributions and gaseous sulfuric acid concentrations, the role of sulfuric acid to NPF is explored in order to answer the following questions: (1) what is the limiting factor to determine the occurrence of the NPF events in Beijing, (2) how do the freshly nucleated particles and nucleation rates depend on the sulfuric acid concentrations, and (3) how do the activation and kinetic nucleation theories apply in the urban environment and what are the differences compared with other atmospheric environments.

\section{Materials and methods}

\subsection{Measurements}

The measurements were conducted at an urban site, the campus of Peking University $\left(39.99^{\circ} \mathrm{N}, 116.31^{\circ} \mathrm{E}\right)$. The observatory is located on the sixth floor of an academic building (about $20 \mathrm{~m}$ above the ground level). Detailed descriptions of the measurement site and surrounding environment can be found in Wu et al. (2008). Both particle number size distributions and sulfuric acid measurements were carried out from 12 July to 25 of September, 2008.

Number size distributions of atmospheric particles from 3 to $900 \mathrm{~nm}$ (mobility diameter) were measured by a TDMPS (Twin Differential Mobility Particle Sizer) system with 10 min time resolution. It consists of two parallel differential mobility analyzers (DMAs) that classify particles in the size ranges $3-80 \mathrm{~nm}$ and $40-900 \mathrm{~nm}$. The relative humidity within the whole system was kept below $30 \%$. The TDMPS system was described in more detail by Wehner et al. (2008).

The gaseous sulfuric acid concentration was measured by an AP-ID-CIMS, which was developed at Texas A\&M Uni- versity. The time resolution was $12 \mathrm{~s}$, and then the data were averaged to $10 \mathrm{~min}$ in order to reduce statistical error and keep consistent with the particle number size distribution. Detailed descriptions of the instrument and the measurement of gaseous sulfuric acid in the same campaign were introduced by Zheng et al. (2011).

\subsection{Data analysis}

\subsubsection{Time delay $\Delta t$ and growth rate GR}

Recent observations and laboratory calculations imply the diameter of the nucleation particles is around $1.5 \mathrm{~nm}$ (Kulmala et al., 2007; Zhang, 2010). The lowest detecting diameter measured by the TDMPS is however $3 \mathrm{~nm}$. Freshly nucleated particles are thus not observed at the same time of their formation but after a time interval $\Delta t$, until they grow up to the diameter of $3 \mathrm{~nm}$. This time delay implies that the increase in the concentration of small particles is preceded by the increase in sulfuric acid concentration. Based on this assumption, the growth rate from the nucleation size $(1.5 \mathrm{~nm}$ in this study) to the detectable size $(3 \mathrm{~nm})$ can be expressed as:

$\mathrm{GR}_{1.5-3}=\frac{3 \mathrm{~nm}-1.5 \mathrm{~nm}}{\Delta t}=\frac{1.5 \mathrm{~nm}}{\Delta t}$

here $\Delta t$ is defined as the time delay between the sulfuric acid concentration and $N_{3-6}$, where $N_{3-6}$ refers to the particle number concentration in the size range 3-6 $\mathrm{nm}$ (covers the five lowest channels of the TDMPS) which could considered as the freshly nucleated particles to a great extent.

However the model simulation results indicate that the time delay method has its limitation, especially in the case of strong particle formation events (Korhonen et al., 2011). The previous formed nucleation mode particles could act as an extra coagulation sink for the small clusters that form later, which may cause the peak of $N_{3-6}$ arised earlier than in the case of purely condensation controlled formation of these small particles. As a result, the time delay between $N_{3-6}$ and sulfuric acid concentration may equal to zero or even negative in these cases. Another possible explanation to the case of no time delay observed is that the rapid growth from nucleation size to detectable size and limitation of instrument (TDMPS) time response. We assume that it may take $10 \mathrm{~min}$ (time resolution of instruments) for particles to grow up from $1.5 \mathrm{~nm}$ to $3 \mathrm{~nm}$ pointing to $\mathrm{GR}_{1.5-3}$ equal to $9 \mathrm{~nm} \mathrm{~h}^{-1}$ (which is (3-1.5) nm $10 \mathrm{~min}$ ). In these cases, the real growth rate should be larger than $9 \mathrm{~nm} \mathrm{~h}^{-1}$.

\subsubsection{Particle formation rates $J_{3}$ and $J_{1.5}$}

The time evolution of $N_{3-6}$ is described with a balance equation:

$\frac{d N_{3-6}}{d t}=\mathrm{GR}_{3} \cdot n_{3}-\mathrm{GR}_{6} \cdot n_{6}-\mathrm{CoagS}_{3-6} \cdot N_{3-6}$

where $n$ is the particle size distribution function, defined as $n_{d}=d N_{d} / d d p$ with the particle diameter $d p$ and $\mathrm{GR}_{d p}$ is the 
growth rate of the particles with diameter $d_{\mathrm{p}}$. The CoagS $\mathrm{S}_{3-6}$ denotes the average coagulation sink for the $3-6 \mathrm{~nm}$ range (Kulmala et al., 2001). Hence, this formula includes terms for the growth into the $3-6 \mathrm{~nm}$ range over the $3 \mathrm{~nm}$ limit (first term), out of the range over the $6 \mathrm{~nm}$ limit (second term) and the loss by coagulation scavenging (third term).

By rearranging the terms, and denoting the first term on the right hand side of Eq. (2) by $J_{3}$, the previous studies (Sihto et al., 2006; Paasonen et al., 2009) gave the Eq. (3) to calculate the particle formation rate at $3 \mathrm{~nm}$ :

$J_{3}=\frac{d N_{3-6}}{d t}+\mathrm{CoagS}_{4} \cdot N_{3-6}+\frac{1}{3 \mathrm{~nm}} \mathrm{GR}_{6} \cdot N_{3-6}$

The approximations made in Eq. (3) are the following: (1) the $\mathrm{CoagS}_{3-6}$ has been approximated by a term representing the loss of $4 \mathrm{~nm}$ sized particles ( $4 \mathrm{~nm}$ is approximately the geometric mean of 3 and $6 \mathrm{~nm}$ ) and $\mathrm{CoagS}_{4}$ could be calculated directly from the measured particle number size distribution, (2) the condensation loss out of the size range 3-6 nm is obtained by approximating $n_{6}$ by $N_{3-6} /(6 \mathrm{~nm}-3 \mathrm{~nm})$ and the $\mathrm{GR}_{6}=\mathrm{GR}$, respectively. Here GR is estimated from the time delay between sulphuric acid and $N_{3-6}$ as shown in the Eq. (1)

However, the recent studies (Vuollekoski et al., 2010; Korhonen et al., 2011) show that there are potential problems in determining $\mathrm{GR}_{1.5-3}$. To improve the accuracy of $J_{3}$ calculation the recommended Eq. (4) is used to simulate the $J_{3}$ value in this study:

$J_{3}=\frac{d N_{3-6}}{d t}+\mathrm{CoagS}_{4} \cdot N_{3-6}+\frac{1}{2 \mathrm{~nm}} \mathrm{GR}_{6} \cdot N_{5-7}$

The first and second terms on the right hand side of Eq. (4) are the same as Eq. (3). The differences between these two equations are: (1) here $\mathrm{n}_{6}$ is assumed roughly equal to $N_{5-7} /(7 \mathrm{~nm}-5 \mathrm{~nm})$ and (2) the $\mathrm{GR}_{6}$ is assumed closer to the growth rate of the nucleation mode $\left(\mathrm{GR}_{3-7}\right.$ estimated from particle number size distribution in this study) than $\mathrm{GR}_{1.5-3}$.

Based on the $J_{3}$ values, the nucleation rate $J_{1.5}$ can be estimated using the method presented by Kerminen and Kulmala (2002):

$J_{1.5}\left(t^{\prime}\right)=J_{3}\left(t^{\prime}\right) \exp \left(\gamma \frac{\mathrm{CS}^{\prime}}{\mathrm{GR}}\left(\frac{1}{1.5 \mathrm{~nm}}-\frac{1}{3 \mathrm{~nm}}\right)\right)$

here $\gamma$ is a coefficient with the approximate value of $0.23 \mathrm{~m}^{2} \mathrm{~nm}^{2} \mathrm{~h}^{-1}$ and $\mathrm{CS}^{\prime}$ is the condensation sink in unit $\mathrm{m}^{-2}$. For the condensation sink $\mathrm{CS}^{\prime}$ we use the median value from the interval $[t, t+\Delta t]$.

However, the simulation of nucleation rate $J_{1.5}$ based on the Eq. (5) has great uncertainty. First the assumption of the constant growth rate in Eq. (5) is suspectable (Korhonen et al., 2011). The combined effect of various precursors could cause a strong deviation from the constant growth rate assumption. Second neglecting the intramodal coagulation in the nucleation mode in Eq. (5) may lead in theory to underestimation of $J_{1.5}$. Third the time shift between the $N_{3-6}$ and sulfuric acid concentration was not observed in most cases of this study. In these cases we have to assume the GR is equal to $9 \mathrm{~nm} \mathrm{~h}^{-1}$ (see Sect. 2.2.1), which may overestimate the real nucleation rate.

\subsubsection{Determination of the nucleation coefficients $A$ and $K$}

In this work, we study two nucleation theories using $J_{1.5}$ estimated from the particle measurement data, the activation theory and the kinetic theory (Kulmala et al., 2006). These theories assume that the nucleation rate should have a power law dependence on the sulfuric acid concentration. In the activation theory, the clusters containing one sulfuric acid molecule will activate for further growth due to heterogeneous nucleation, thus the nucleation rate is directly proportional to the sulfuric acid concentration:

$J_{1.5}=A\left[\mathrm{H}_{2} \mathrm{SO}_{4}\right]$

where $A$ is the activation coefficient (in unit $\mathrm{s}^{-1}$ ).

The kinetic theory (McMurry and Friedlander, 1979; Lushnikov and Kulmala, 1998) suggests that critical clusters are formed by collisions of two sulfuric acid molecules. According to kinetic gas theory, the collision frequency of two molecules is correlated with the concentration of both molecules. The nucleation rate can thus be written as:

$J_{1.5}=K\left[\mathrm{H}_{2} \mathrm{SO}_{4}\right]^{2}$

where $K$ is the kinetic coefficient (in unit $\mathrm{cm}^{3} \mathrm{~s}^{-1}$ ).

According to previous studies (Sihto et al., 2006), the relationship between nucleation rate and sulfuric acid concentration is in general within the exponent between 1 and 2 which signifies the reasonability of these two theories. On the other hand, the exponents for $J_{1.5} \mathrm{vs}$. $\mathrm{H}_{2} \mathrm{SO}_{4}$ clearly in excess of 2 are also observed in some cases (Riipinen et al., 2007; Kuang et al., 2008), which indicate that the atmospheric nucleation is thermodynamically limited (Kulmala et al., 2006). In these cases, the nucleation theory is defined as:

$J_{1.5}=T\left[\mathrm{H}_{2} \mathrm{SO}_{4}\right]^{n}(n>2.5)$

where $T$ is the thermodynamic coefficient (in unit $\left.\mathrm{cm}^{(3 n-3)} \mathrm{s}^{-1}\right)$.

\section{Results and discussion}

\subsection{Comparisons of sulfuric acid concentration and condensation sink between the NPF and non-NPF days}

The improved air quality during 2008 Olympic Games (UNEP, 2009) with less pre-existing particles enhances the NPF. The frequency of the NPF event $(26 \%)$ is higher than our previous studies in the same period of 2004-2007 (11\%$20 \%$ ) (Wu et al., 2007; Yue et al., 2009). In total, 22 NPF 


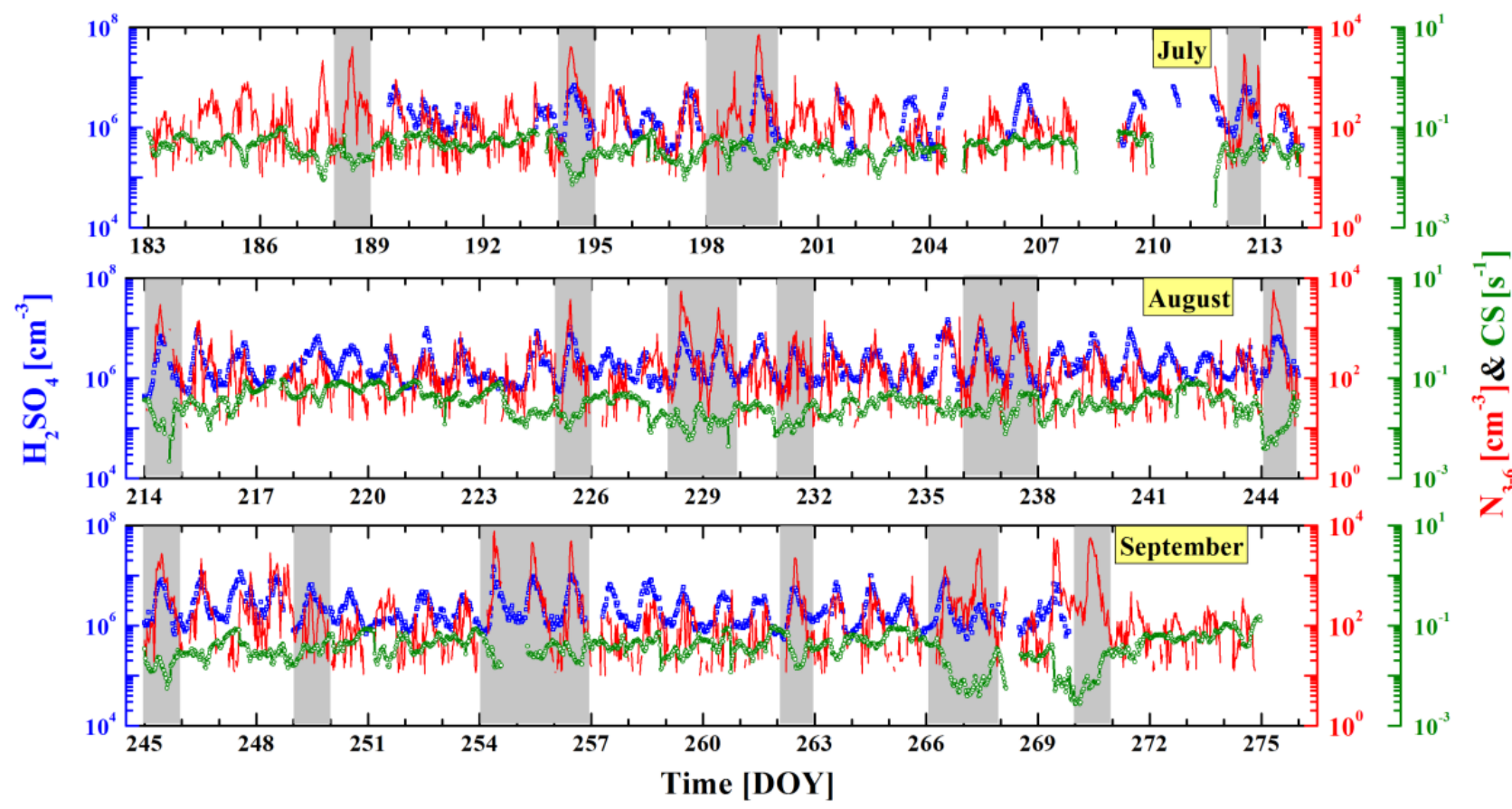

Fig. 1. Time series for the sulfuric acid $\left(\mathrm{H}_{2} \mathrm{SO}_{4}\right.$, blue empty dot), condensation sink (CS, green line with empty dot), and 3-6 nm particle number concentrations $\left(N_{3}-6\right.$, red line) for the whole measurement period. The NPF event days are presented on gray background. The $\mathrm{x}$-axis is presented by DOY (day of year), 1 January is defined as day 1.
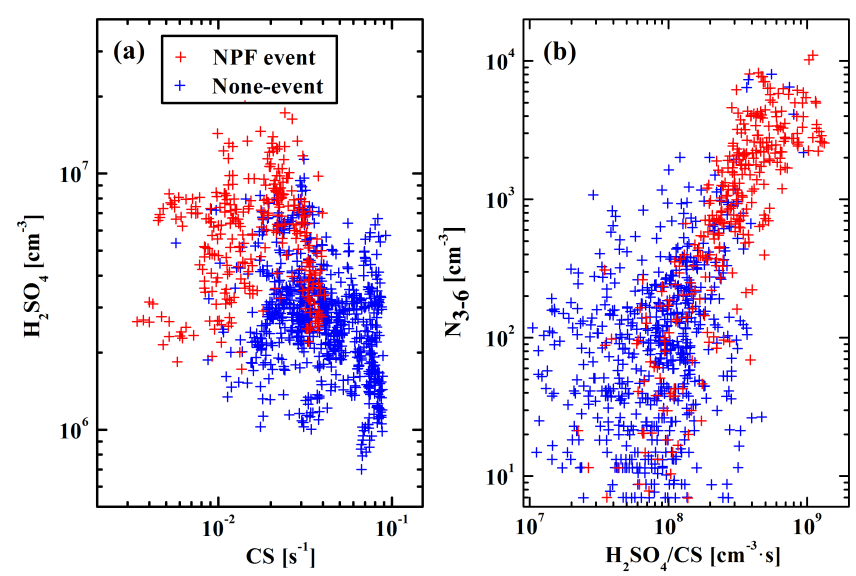

Fig. 2. The relationships between (a) sulfuric acid concentrations and condensation sink, and (b) the number concentration of 3-6 nm particles and the ratio of sulfuric acid concentration to condensation sink. The data are 10 min integrated between 08:00 and 11:00. NPF event days (red), None-event days (blue).

events are identified out of 85 days from July to September 2008, in which on 17 NPF events both particle number size distributions and sulfuric acid concentrations are simultaneously measured. In this paper, freshly nucleated particles in the size range from 3 to $6 \mathrm{~nm}$ are chosen to examine its connection with sulfuric acid concentration. Figure 1 displays the temporal variations of the sulfuric acid $\left(\mathrm{H}_{2} \mathrm{SO}_{4}\right)$, condensation sink (CS) and 3-6 nm particle number concentrations $\left(N_{3-6}\right)$ for the whole measurement period. It is evident that both the $N_{3-6}$ and $\mathrm{H}_{2} \mathrm{SO}_{4}$ have the strong diurnal variations on NPF days (gray background). During some non-event days however, even the $\mathrm{H}_{2} \mathrm{SO}_{4}$ concentration goes up to equal levels compared to the event days (e.g. $17 \mathrm{Au}-$ gust, day 230 and 2 September, day 247). On these days, an increase in nucleation mode particles with the $\mathrm{H}_{2} \mathrm{SO}_{4}$ concentration is not observed. This phenomenon may be due to the high concentration of pre-existing particles, which is also visible in the large CS values. The pre-existing particles could act as a sink to capture for both, condensing vapors and newly formed particles, which could prevent the occurrence of NPF events.

Figure 2a shows the comparison between sulfuric acid concentrations and condensation sink values of NPF-event and non-event days before the nucleation events start (8:0011:00). It can be seen clearly that on average, the event days are associated with lower condensation sinks than the non-event days. The mean CS (during 8:00-11:00) on NPF event days $\left(0.022 \mathrm{~s}^{-1}\right)$ is typically significantly lower than on non-event days $\left(0.045 \mathrm{~s}^{-1}\right)$. Even though during NPF event days, the CS value are higher than other observations in clean environments (Riipinen et al., 2007; Boy et al., 2008) or polluted regions (Kulmala et al., 2005; Hamed et al., 2007). 


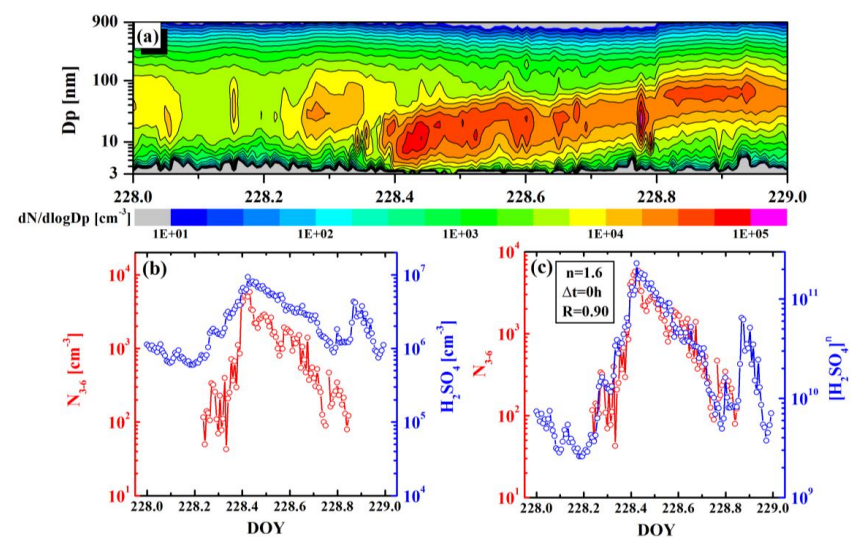

Fig. 3. An example of new particle formation day on 15 August 2008 (day 228) in Beijing. (a) Particle number size distribution, (b) the number concentration of 3-6 nm particles (red) and the sulfuric acid concentration (blue), (c) the number concentration of 3-6 nm particles and the sulfuric acid concentration delayed by the time shift $(\Delta t=0 \mathrm{~h})$ and raised to the fitted power $(n=1.6)$ with the best correlation $(R=0.90)$.

In addition, the abundant $\mathrm{SO}_{2}$ concentrations and the high oxidation capacity in the polluted urban environment of Beijing indicates the sufficient source of sulfuric acid (Wu et al., 2007; Yue et al., 2010). The higher number concentration of newly formed particles is observed when the ratio of sulfuric acid concentration to condensation sink is larger, which is shown in Fig. 2b. The NPF event is the product of the competition between source (here represented as sulfuric acid concentration) and sink (CS). In the case of both higher source and sink values, the result of the competition between source and sink is more likely the key limiting factor to determine the observation of NPF events in the urban of Beijing.

\subsection{Correlation between freshly nucleated particles and sulfuric acid concentration}

The concentrations of newly formed particles and sulfuric acid are obviously correlated on the 17 NPF event days. Figures $3 \mathrm{a}$ and $4 \mathrm{a}$ show two typical cases of the NPF events observed on 15 August (day 228) and 12 September (day 256), respectively. In both cases a significant nucleation mode is formed around 10:00 and followed by particle growth until the next day. The condensational sink of pre-existing particles before the nucleation event on $15 \mathrm{Au}$ gust $\left(C S=0.014 \mathrm{~s}^{-1}\right)$ is lower than that on 12 September $\left(C S=0.038 \mathrm{~s}^{-1}\right)$. The initial concentration of pre-existing particles may affect the nucleation process and will be discussed later.

Figures $3 \mathrm{~b}$ and $4 \mathrm{~b}$ display the diurnal variations of $N_{3-6}$ and sulfuric acid concentrations in two cases, respectively. Unlike other studies (Riipinen et al., 2007; Kuang et al., 2008; Paasonen et al., 2009), the time shift between the rise of $N_{3-6}$ and sulfuric acid concentrations in both cases is

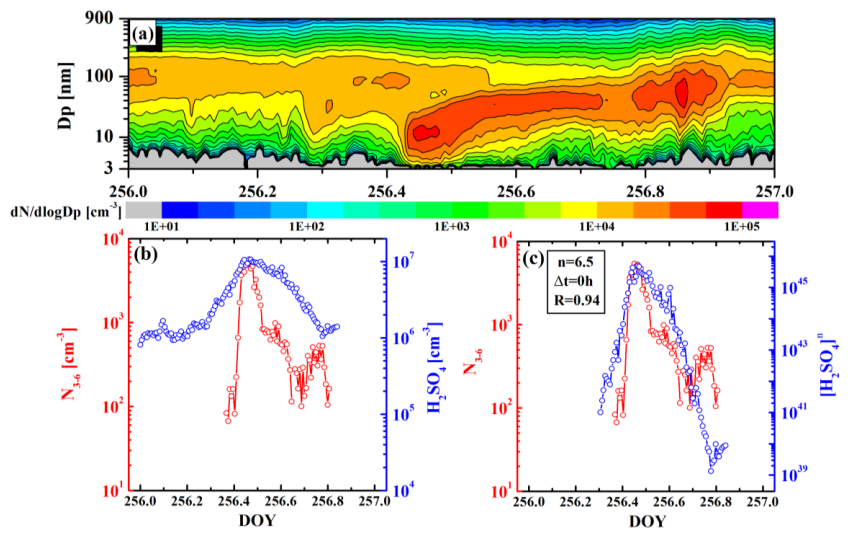

Fig. 4. An example of new particle formation day on 12 September 2008 (day 256) in Beijing. (a) particle number size distribution, (b) the number concentration of 3-6 nm particles (red) and the sulfuric acid concentration (blue), (c) the number concentration of 3-6 nm particles and the $s$ sulfuric acid concentration delayed by the time shift $(\Delta t=0 \mathrm{~h})$ and raised to the fitted power $(n=6.5)$ with the best correlation $(R=0.94)$.

not observed. Besides the potential problem in Eq. (1), the rapid growth from cluster size to detectable size may also cause this issue as discussed before. The growth rate in the size range from 3 to $10 \mathrm{~nm}$ are $20.1 \mathrm{~nm} \mathrm{~h}^{-1}$ (15 August) and $36.1 \mathrm{~nm} \mathrm{~h}^{-1}$ (12 September), respectively. The best correlations are 0.90 on 15 August with the exponent 1.6 and 0.94 on 12 September with the exponent 6.5 , respectively (see Figs. $3 c$ and $4 c$ ).

In order to compare our results with the other studies, we choose the same classification as described in Riipinen et al. (2007). The statistic results are shown in Table 1 . The mean value of the correlation coefficient is 0.86 ( $R$ in the range 0.67-0.96) which reflects a good correlation between $N_{3-6}$ and sulfuric acid. Different from the other studies, with exponents between 1 and 2, the NPF event days of this study, lead to exponents more concentrated between 2.5 and 7 (58\% in 17 investigated days). In addition, we find the exponents of sulfuric acid increase with the CS values in these four categories of Beijing. The mean CS values (8:00-11:00 during nucleation days) are $0.008 \mathrm{~s}^{-1}(n \sim 1), 0.012 \mathrm{~s}^{-1}(n \sim$ $1.5), 0.019 \mathrm{~s}^{-1}(n \sim 2)$ and $0.024 \mathrm{~s}^{-1}(n>2.5)$, respectively. The exponent in the correlation of $N_{3-6}$ and sulfuric acid concentrations might be related to the background particle concentration and atmosphere nucleation precursors. Therefore, more information on the nucleation process and chemical composition of freshly formed particles is needed. 
Table 1. Comparisons of the exponent in the correlation of $N_{3-6}$ and sulfuric acid concentrations with other studies. $R$ refers to the correlation coefficient. $N(\%): N$ is the number of nucleation event and the value in bracket indicates the percentage accounting for.

\begin{tabular}{lrrrr}
\hline & Hyytiälä & Heidelberg & $\begin{array}{r}\text { Hyytiälä } \\
\text { QUEST II }\end{array}$ & $\begin{array}{r}\text { QUEST III } \\
\text { BACCI/QUEST IV }\end{array}$ \\
\begin{tabular}{lrrrr} 
CAREBeijing 2008 \\
\hline$n \sim 1$
\end{tabular} & $6(38 \%)$ & $6(60 \%)$ & $9(45 \%)$ & $2(12 \%)$ \\
$n \sim 1.5$ & $4(25 \%)$ & $3(30 \%)$ & $2(10 \%)$ & $2(12 \%)$ \\
$n \sim 2$ & $5(31 \%)$ & $1(10 \%)$ & $6(30 \%)$ & $3(18 \%)$ \\
$n>2.5$ & $1(6 \%)$ & - & $3(15 \%)$ & $10(58 \%)$ \\
Mean $R$ & 0.85 & 0.75 & 0.82 & 0.86 \\
Ref. & \multicolumn{3}{c}{ Riipinen et al. (2007) } \\
\hline
\end{tabular}

\subsection{Correlation between particle formation rates and sulfuric acid concentration}

The formation rates are calculated based on the particle number size distributions using Eq. (4). Figure 5 shows the diurnal variations of $J_{3}$ values and sulfuric acid concentrations during the two selected days. A good correlation is observed between $J_{3}$ and sulfuric acid and for the $N_{3-6}$ and sulfuric acid.

The formation rates $J_{3}$ and $J_{1.5}$ are plotted versus the sulfuric acid concentrations in Fig. 6. It is obviously that the exponents in the relationships between particle formation rates (both $J_{3}$ and $J_{1.5}$ ) and sulfuric acid concentrations are mostly between 1 and 7 in Beijing. It is hard to distinguish the dominative nucleation theories depend on the scatter data plots. The average slopes for the 17 days data set are $2.3\left(J_{3}\right)$ and $2.7\left(J_{1.5}\right)$, respectively. These values are higher than obtained during the studies in Hyytiälä, Heidelberg or other stations, where the exponents are always between 1 and 2 (Riipinen et al., 2007; Nieminen et al., 2009; Sipila et al., 2010). These results indicate that in the polluted urban environment of Beijing, the thermodynamic process seems involved in the nucleation process, which could not simply explained by activation or kinetic nucleation theory as previous studies.

\subsection{Nucleation coefficients}

Two cases of the NPF events are observed in Beijing, as mentioned above: (1) the exponent in the correlation of the formation rate and sulfuric acid between 1 and 2, which implies that activation or kinetic nucleation is the possible main nucleation mechanism; (2) the exponent larger than 2.5 indicates that thermodynamic nucleation is the dominate mechanism. The first case is similar with the observations in clean environments (Sihto et al., 2006; Riipinen et al., 2007). In the polluted urban environment of Beijing, more than half of the NPF events ( $58 \%$ ) belong to the second case.

The nucleation activation coefficients $A$ and kinetic coefficient $K$ are calculated by using the Eqs. (1) and (7). The formation rates $\left(J_{1.5}\right)$ calculated from particle number size distributions and the sulfuric acid concentrations are com-

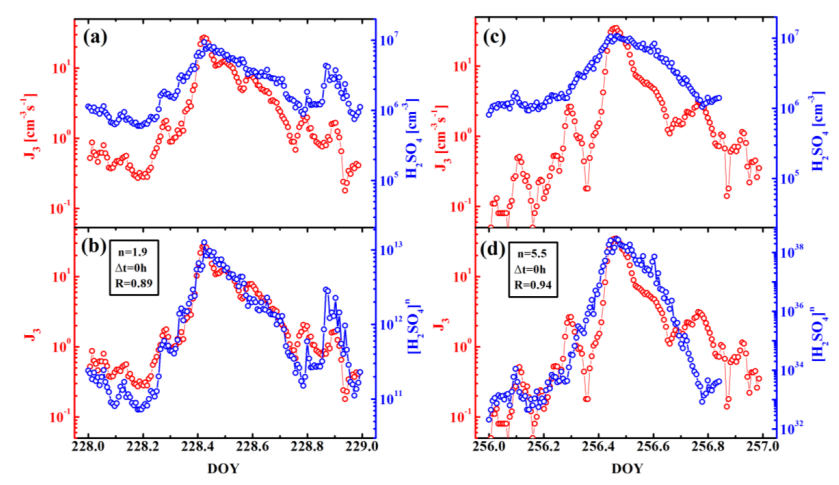

Fig. 5. The correlation of $J_{3}$ values (red) and sulfuric acid concentrations (blue) on 15 August (left panel) and 12 September 2008 (right panel) in Beijing. (a) and (c): the diurnal variation of $J_{3}$ values and the sulfuric acid concentrations, (b) and (d): the $J_{3}$ values and the sulfuric acid concentrations delayed by the time shift and raised to the fitted power with the best correlation.
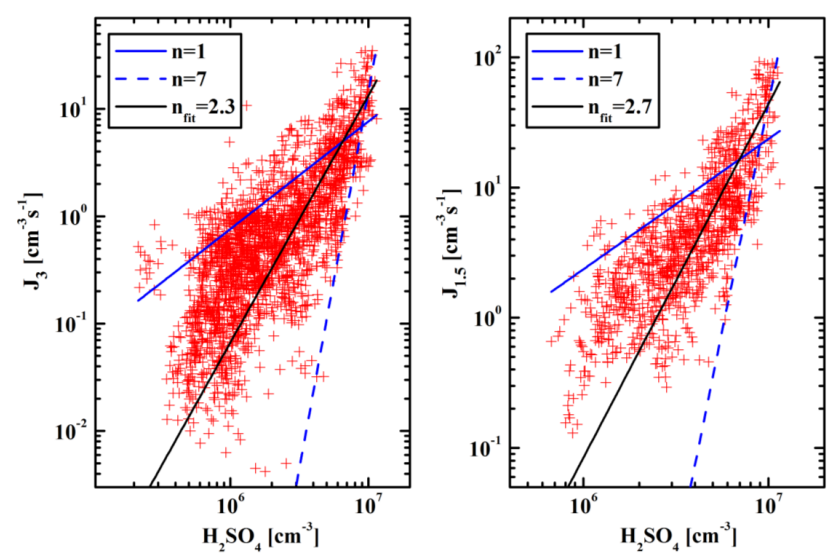

Fig. 6. The formation rate $J_{3}$ and $J_{1.5}$ estimated from particle number size distributions versus the sulfuric acid concentrations. Blue lines represent the slopes with $n=1$ and $n=7$ in $\left[\mathrm{H}_{2} \mathrm{SO}_{4}\right]^{n}$. Black line represents the average value for the exponent in the entire data set.

pared in Fig. 7. It illustrates the correlation between the results from particle size distribution and sulfuric acid measurements on two cases of NPF event days: the exponent between 1 and 2 on 15 August, while greater than 3 on 12 September. On 15 August, the correlation coefficients between activation nucleation and kinetic nucleation are almost the same and the difference is negligible. The kinetic nucleation theory fits better than the activation theory on 12 September. In contrast, the thermodynamic process seems more reasonable than the other two theories (thermodynamic coefficient $T$ are calculated by using the Eq. (8) with the exponent equal to 3 ).

In order to facilitate comparison with other studies, the nucleation coefficients $A$ and $K$ are calculated for all the 
Table 2. Comparison of the mean values of the activation $A$ and kinetic coefficients $K$.

\begin{tabular}{lllrrl}
\hline Site & $\begin{array}{l}\text { Sampling } \\
\text { Period }\end{array}$ & $\begin{array}{l}\text { Air Mass } \\
\text { Type }\end{array}$ & $\begin{array}{r}\text { Mean } A \\
\left(10^{-6} \mathrm{~s}^{-1}\right)\end{array}$ & $\begin{array}{r}\text { Mean } K \\
\left(10^{-13} \mathrm{~cm}^{3} \mathrm{~s}^{-1}\right)\end{array}$ & Ref. \\
\hline Hohenpeissenberg $^{\mathrm{a}}$ & 1998-2000 & mountain forest & 0.16 & 0.32 & Paasonen et al. (2009) \\
Hyytiäläb $^{\mathrm{b}}$ & Mar-Apr 2003 & boreal forest & 1.70 & 5.70 & Sihto et al. (2006) \\
Heidelberg $^{\mathrm{b}}$ & Feb-Apr 2004 & semi-urban & 77.00 & 230.00 & Riipinen et al. (2007) \\
Hyytiäläa $^{\mathrm{b}}$ & Apr-May 2005 & boreal forest & 0.35 & 0.55 & Riipinen et al. (2007) \\
MRS $^{\mathrm{c}}$ & Jun-Jul 2006 & mountain forest & 0.28 & 0.18 & Boy et al. (2008) \\
Hyytiäläc $_{\text {Beijing }}^{\text {Mar-Jun 2007 }}$ & boreal forest & 0.32 & 2.70 & Nieminen et al. (2009) \\
\hline
\end{tabular}

a median nucleation rate: $J_{1.5}$;

b nucleation rate: $J_{1}$;

c nucleation rate: $J_{2}$.

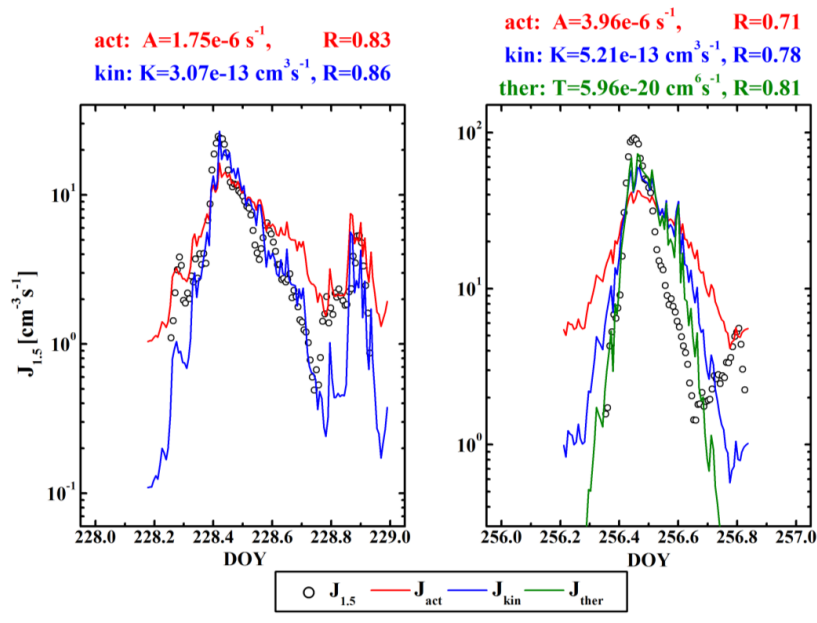

Fig. 7. Nucleation rate $\left(J_{1.5}\right)$ on 15 August (left panel) and 12 September (right panel) estimated from the particle number size distribution measurements and calculated from the sulfuric acid concentration using the activation and kinetic nucleation mechanisms. Also the thermodynamic coefficient is calculated on 12 September.

events regardless of which nucleation mechanism obtained for that particular event. The results are summarized in Table 2. During the 17 NPF event days, the mean values of the activation coefficient is $1.95 \times 10^{-6} \mathrm{~s}^{-1}$ ranging from $0.72 \times 10^{-6} \mathrm{~s}^{-1}$ to $5.01 \times 10^{-6} \mathrm{~s}^{-1}$, and the mean values of kinetic coefficient is $3.44 \times 10^{-13} \mathrm{~cm}^{3} \mathrm{~s}^{-1}$ varying from $1.24 \times 10^{-13} \mathrm{~cm}^{3} \mathrm{~s}^{-1}$ to $8.18 \times 10^{-13} \mathrm{~cm}^{3} \mathrm{~s}^{-1}$. Compared to the coefficients $A$ and $K$ calculated at Hohenpeissenberg, in Hyytiälä, and in the Rocky Mountains, the $A$ values are between $10^{-8}$ and $10^{-6} \mathrm{~s}^{-1}$ and the $K$ values are between $10^{-14}$ and $10^{-12} \mathrm{~cm}^{3} \mathrm{~s}^{-1}$, which is in the same order as chemical reaction rate coefficients in the gas phase (Sihto et al., 2006).

\section{Conclusions}

This paper focuses on the Beijing case of the NPF in the polluted urban environment. Field-based discussion is made to explore the nucleation mechanism and the role of sulfuric acid. The following conclusions are made.

The mean CS during the time period of 08:00-11:00 on the NPF event days is about half of that in non-event days. The results reveal that in the case of both higher source and sink values, the result of the competition between source and sink is more likely the limiting factors to determine the occurrence of a nucleation event.

Good correlation $(R=0.86)$ between $N_{3-6}$ and sulfuric acid are observed in Beijing. The correlation coefficient values vary from 0.67 to 0.96 . Most of the NPF events in Beijing are observed without the time delay between the detection of freshly formed particles and the occurrence of sulfuric acid, which is rarely observed previously. The exponent is larger in other studies, more than half of them are larger than 2.5. Meanwhile, the exponents of sulfuric acid increasing with the CS values are observed in Beijing case.

Formation rates of $3 \mathrm{~nm}$ and $1.5 \mathrm{~nm}$ particles estimated from particle measurements are correlated with sulfuric acid concentration to the power from 1 to 7 in this study. The mean slopes for the 17 days data set are $2.3\left(J_{3}\right)$ and 2.7 $\left(J_{1.5}\right)$, respectively. In more than half of all cases, the thermodynamic process works better than the activation and kinetic nucleation theories, which is different from the previous literatures. The mean values of activation and kinetic coefficient are $1.95 \times 10^{-6} \mathrm{~s}^{-1}$ and $3.44 \times 10^{-13} \mathrm{~cm}^{3} \mathrm{~s}^{-1}$, respectively. The values of $A$ and $K$ are in the same order as the previous studies.

The larger exponent between particle formation rates and sulfuric acid concentrations implies that besides $\mathrm{H}_{2} \mathrm{SO}_{4}$, also other species such as low-volatility organic vapors might be involved in the early stage of NPF events in Beijing. Future investigations on the role of organic compounds in the 
initial nucleation process are required and the comparisons with previous studies in other atmosphere environments are very important.

Acknowledgements. This work is supported by the National Natural Science Foundation of China (20977001, 21025728), China Ministry of Environmental Protection's Special Funds for Scientific Research on Public Welfare (201009002), and LAIC (Land-Atmosphere Interactions in China) project. The authors also would like to thank the cooperation and help of the CAREBeijing 2008 team.

Edited by: D. Parrish

\section{References}

Berndt, T., Boge, O., Stratmann, F., Heintzenberg, J., and Kulmala, M.: Rapid formation of sulfuric acid particles at near-atmospheric conditions, Science, 307, 698-700, doi:10.1126/science.1104054, 2005.

Bonn, B., Kulmala, M., Riipinen, I., Sihto, S. L., and Ruuskanen, T. M.: How biogenic terpenes govern the correlation between sulfuric acid concentrations and new particle formation, J. Geophys. Res., 113, D12209, doi:10.1029/2007jd009327, 2008.

Boy, M., Karl, T., Turnipseed, A., Mauldin, R. L., Kosciuch, E., Greenberg, J., Rathbone, J., Smith, J., Held, A., Barsanti, K., Wehner, B., Bauer, S., Wiedensohler, A., Bonn, B., Kulmala, M., and Guenther, A.: New particle formation in the Front Range of the Colorado Rocky Mountains, Atmos. Chem. Phys., 8, 15771590, doi:10.5194/acp-8-1577-2008, 2008.

Dunn, M. J., Jimenez, J. L., Baumgardner, D., Castro, T., McMurry, P. H., and Smith, J. N.: Measurements of Mexico City nanoparticle size distributions: Observations of new particle formation and growth, Geophys. Res. Lett., 31, L10102, doi:10.1029/2004g1019483, 2004.

Fiedler, V., Dal Maso, M., Boy, M., Aufmhoff, H., Hoffmann, J., Schuck, T., Birmili, W., Hanke, M., Uecker, J., Arnold, F., and Kulmala, M.: The contribution of sulphuric acid to atmospheric particle formation and growth: a comparison between boundary layers in Northern and Central Europe, Atmos. Chem. Phys., 5, 1773-1785, doi:10.5194/acp-5-1773-2005, 2005.

Hamed, A., Joutsensaari, J., Mikkonen, S., Sogacheva, L., Dal Maso, M., Kulmala, M., Cavalli, F., Fuzzi, S., Facchini, M. C., Decesari, S., Mircea, M., Lehtinen, K. E. J., and Laaksonen, A.: Nucleation and growth of new particles in Po Valley, Italy, Atmos. Chem. Phys., 7, 355-376, doi:10.5194/acp-7-355-2007, 2007.

Holmes, N. S.: A review of particle formation events and growth in the atmosphere in the various environments and discussion of mechanistic implications, Atmos. Environ., 41, 2183-2201, doi:10.1016/j.atmosenv.2006.10.058, 2007.

Kerminen, V. M. and Kulmala, M.: Analytical formulae connecting the "real" and the "apparent" nucleation rate and the nuclei number concentration for atmospheric nucleation events, J. Aerosol. Sci., 33, 609-622, doi:S0021-8502(01)00194-X, 2002.

Korhonen, P., Kulmala, M., Laaksonen, A., Viisanen, Y., McGraw, R., and Seinfeld, J. H.: Ternary nucleation of $\mathrm{H}_{2} \mathrm{SO}_{4}, \mathrm{NH}_{3}$, and $\mathrm{H}_{2} \mathrm{O}$ in the atmosphere, J. Geophys. Res., 104, 26349-26353, 1999.
Korhonen, H., Sihto, S.-L., Kerminen, V.-M., and Lehtinen, K. E. J.: Evaluation of the accuracy of analysis tools for atmospheric new particle formation, Atmos. Chem. Phys., 11, 3051-3066, doi:10.5194/acp-11-3051-2011, 2011.

Kuang, C., McMurry, P. H., McCormick, A. V., and Eisele, F. L.: Dependence of nucleation rates on sulfuric acid vapor concentration in diverse atmospheric locations, J. Geophys. Res., 113, D10209, doi:10.1029/2007jd009253, 2008.

Kulmala, M.: How particles nucleate and grow, Science, 302, 10001001, 2003.

Kulmala, M., Dal Maso, M., Makela, J. M., Pirjola, L., Vakeva, M., Aalto, P., Miikkulainen, P., Hameri, K., and O'Dowd, C. D.: On the formation, growth and composition of nucleation mode particles, Tellus B, 53, 479-490, 2001.

Kulmala, M., Vehkamaki, H., Petaja, T., Dal Maso, M., Lauri, A., Kerminen, V. M., Birmili, W., and McMurry, P. H.: Formation and growth rates of ultrafine atmospheric particles: a review of observations, J. Aerosol. Sci., 35, 143-176, doi:10.1016/j.jaerosci.2003.10.003, 2004.

Kulmala, M., Petäjä, T., Mönkkönen, P., Koponen, I. K., Dal Maso, M., Aalto, P. P., Lehtinen, K. E. J., and Kerminen, V.-M.: On the growth of nucleation mode particles: source rates of condensable vapor in polluted and clean environments, Atmos. Chem. Phys., 5, 409-416, doi:10.5194/acp-5-409-2005, 2005.

Kulmala, M., Lehtinen, K. E. J., and Laaksonen, A.: Cluster activation theory as an explanation of the linear dependence between formation rate of $3 \mathrm{~nm}$ particles and sulphuric acid concentration, Atmos. Chem. Phys., 6, 787-793, doi:10.5194/acp-6-787-2006, 2006.

Kulmala, M., Riipinen, I., Sipila, M., Manninen, H. E., Petaja, T., Junninen, H., Dal Maso, M., Mordas, G., Mirme, A., Vana, M., Hirsikko, A., Laakso, L., Harrison, R. M., Hanson, I., Leung, C., Lehtinen, K. E. J., and Kerminen, V. M.: Toward direct measurement of atmospheric nucleation, Science, 318, 89-92, doi:10.1126/science.1144124, 2007.

Lauros, J., Sogachev, A., Smolander, S., Vuollekoski, H., Sihto, S.L., Mammarella, I., Laakso, L., Rannik, Ü., and Boy, M.: Particle concentration and flux dynamics in the atmospheric boundary layer as the indicator of formation mechanism, Atmos. Chem. Phys., 11, 5591-5601, doi:10.5194/acp-11-5591-2011, 2011.

Lohmann, U. and Feichter, J.: Global indirect aerosol effects: a review, Atmos. Chem. Phys., 5, 715-737, doi:10.5194/acp-5-7152005, 2005.

Lushnikov, A. A. and Kulmala, M.: Dimers in nucleating vapors, Phys. Rev. E, 58, 3157-3167, 1998.

McMurry, P. H. and Friedlander, S. K.: New particle formation in the presence of an aerosol, Atmos. Environ., 13, 1635-1651, doi:10.1016/0004-6981(79)90322-6, 1979.

Merikanto, J., Spracklen, D. V., Mann, G. W., Pickering, S. J., and Carslaw, K. S.: Impact of nucleation on global CCN, Atmos. Chem. Phys., 9, 8601-8616, doi:10.5194/acp-9-8601-2009, 2009.

Napari, I., Kulmala, M., and Vehkamaki, H.: Ternary nucleation of inorganic acids, ammonia, and water, J. Chem. Phys., 117, 8418-8425, doi:10.1063/1.1511722, 2002.

Nieminen, T., Manninen, H. E., Sihto, S. L., Yli-Juuti, T., Mauldin, R. L., Petaja, T., Riipinen, I., Kerminen, V. M., and Kulmala, M.: Connection of Sulfuric Acid to Atmospheric Nucleation in Boreal Forest, Environ. Sci. Technol., 43, 4715-4721, 
doi:10.1021/Es803152j, 2009.

Paasonen, P., Sihto, S. L., Nieminen, T., Vuollekoski, H., Riipinen, I., Plass-Dulmer, C., Berresheim, H., Birmili, W., and Kulmala, M.: Connection between new particle formation and sulphuric acid at Hohenpeissenberg (Germany) including the influence of organic compounds, Boreal Environ Res, 14, 616-629, 2009.

Paasonen, P., Nieminen, T., Asmi, E., Manninen, H. E., Petäjä, T., Plass-Dülmer, C., Flentje, H., Birmili, W., Wiedensohler, A., Hrrak, U., Metzger, A., Hamed, A., Laaksonen, A., Facchini, M. C., Kerminen, V.-M., and Kulmala, M.: On the roles of sulphuric acid and low-volatility organic vapours in the initial steps of atmospheric new particle formation, Atmos. Chem. Phys., 10, 11223-11242, doi:10.5194/acp-10-11223-2010, 2010.

Riipinen, I., Sihto, S.-L., Kulmala, M., Arnold, F., Dal Maso, M., Birmili, W., Saarnio, K., Teinilä, K., Kerminen, V.-M., Laaksonen, A., and Lehtinen, K. E. J.: Connections between atmospheric sulphuric acid and new particle formation during QUEST IIIIV campaigns in Heidelberg and Hyytiälä, Atmos. Chem. Phys., 7, 1899-1914, doi:10.5194/acp-7-1899-2007, 2007.

Salma, I., Borsós, T., Weidinger, T., Aalto, P., Hussein, T., Dal Maso, M., and Kulmala, M.: Production, growth and properties of ultrafine atmospheric aerosol particles in an urban environment, Atmos. Chem. Phys., 11, 1339-1353, doi:10.5194/acp-111339-2011, 2011.

Sihto, S.-L., Kulmala, M., Kerminen, V.-M., Dal Maso, M., Petäjä, T., Riipinen, I., Korhonen, H., Arnold, F., Janson, R., Boy, M., Laaksonen, A., and Lehtinen, K. E. J.: Atmospheric sulphuric acid and aerosol formation: implications from atmospheric measurements for nucleation and early growth mechanisms, Atmos. Chem. Phys., 6, 4079-4091, doi:10.5194/acp-6-4079-2006, 2006.

Sipila, M., Berndt, T., Petaja, T., Brus, D., Vanhanen, J., Stratmann, F., Patokoski, J., Mauldin, R. L., Hyvarinen, A. P., Lihavainen, H., and Kulmala, M.: The Role of Sulfuric Acid in Atmospheric Nucleation, Science, 327, 1243-1246, doi:10.1126/science.1180315, 2010.

Smith, J. N., Dunn, M. J., VanReken, T. M., Iida, K., Stolzenburg, M. R., McMurry, P. H., and Huey, L. G.: Chemical composition of atmospheric nanoparticles formed from nucleation in Tecamac, Mexico: Evidence for an important role for organic species in nanoparticle growth, Geophys. Res. Lett., 35, L04808, doi:10.1029/2007g1032523, 2008.

Spracklen, D. V., Carslaw, K. S., Kulmala, M., Kerminen, V. M., Sihto, S. L., Riipinen, I., Merikanto, J., Mann, G. W., Chipperfield, M. P., Wiedensohler, A., Birmili, W., and Lihavainen, H.: Contribution of particle formation to global cloud condensation nuclei concentrations, Geophys. Res. Lett., 35, L06808, doi:10.1029/2007g1033038, 2008.

Stier, P., Seinfeld, J. H., Kinne, S., and Boucher, O.: Aerosol absorption and radiative forcing, Atmos. Chem. Phys., 7, 52375261, doi:10.5194/acp-7-5237-2007, 2007.
Vehkamaki, H., Kulmala, M., Napari, I., Lehtinen, K. E. J., Timmreck, C., Noppel, M., and Laaksonen, A.: An improved parameterization for sulfuric acid-water nucleation rates for tropospheric and stratospheric conditions, J. Geophys. Res., 107, 4622, doi:10.1029/2002jd002184, 2002.

Vuollekoski, H., Sihto, S.-L., Kerminen, V.-M., Kulmala, M., and Lehtinen, K. E. J.: A numerical comparison of different methods for determining the particle formation rate, Atmos. Chem. Phys. Discuss., 10, 18781-18805, doi:10.5194/acpd-10-187812010, 2010.

Weber, R. J., Mcmurry, P. H., Eisele, F. L., and Tanner, D. J.: Measurement of Expected Nucleation Precursor Species and 3500 Nm Diameter Particles at Mauna-Loa-Observatory, Hawaii, J. Atmos. Sci., 52, 2242-2257, 1995.

Weber, R. J., McMurry, P. H., Mauldin, R. L., Tanner, D. J., Eisele, F. L., Clarke, A. D., and Kapustin, V. N.: New particle formation in the remote troposphere: A comparison of observations at various sites, Geophys. Res. Lett., 26, 307-310, 1999.

Wehner, B., Birmili, W., Ditas, F., Wu, Z., Hu, M., Liu, X., Mao, J., Sugimoto, N., and Wiedensohler, A.: Relationships between submicrometer particulate air pollution and air mass history in Beijing, China, 2004-2006, Atmos. Chem. Phys., 8, 6155-6168, doi:10.5194/acp-8-6155-2008, 2008.

Wu, Z., Hu, M., Liu, S., Wehner, B., Bauer, S., Ma Bling, A., Wiedensohler, A., Petäjä, T., Dal Maso, M., and Kulmala, M.: New particle formation in Beijing, China: Statistical analysis of a $1 \mathrm{yr}$ data set, J. Geophys. Res., 112, D09209, doi:10.1029/2006jd007406, 2007.

Wu, Z. J., Hu, M., Lin, P., Liu, S., Wehner, B., and Wiedensohler, A.: Particle number size distribution in the urban atmosphere of Beijing, China, Atmos. Environ., 42, 7967-7980, doi:10.1016/j.atmosenv.2008.06.022, 2008.

Yu, F. Q. and Turco, R. P.: Ultrafine aerosol formation via ionmediated nucleation, Geophys. Res. Lett., 27, 883-886, 2000.

Yue, D. L., Hu, M., Wu, Z. J., Wang, Z. B., Guo, S., Wehner, B., Nowak, A., Achtert, P., Wiedensohler, A., Jung, J., Kim, Y. J., and Liu, S.: Characteristics of aerosol size distributions and new particle formation in the summer in Beijing, J. Geophys. Res., 114, D00G12, doi:10.1029/2008jd010894, 2009.

Yue, D. L., Hu, M., Zhang, R. Y., Wang, Z. B., Zheng, J., Wu, Z. J., Wiedensohler, A., He, L. Y., Huang, X. F., and Zhu, T.: The roles of sulfuric acid in new particle formation and growth in the mega-city of Beijing, Atmos. Chem. Phys., 10, 4953-4960, doi:10.5194/acp-10-4953-2010, 2010.

Zhang, R. Y.: Getting to the Critical Nucleus of Aerosol Formation, Science, 328, 1366-1367, doi:10.1126/science.1189732, 2010.

Zheng, J., Hu, M., Zhang, R., Yue, D., Wang, Z., Guo, S., Li, X., Bohn, B., Shao, M., He, L., Huang, X., Wiedensohler, A., and Zhu, T.: Measurements of gaseous $\mathrm{H}_{2} \mathrm{SO}_{4}$ by AP-ID-CIMS during CAREBeijing 2008 Campaign, Atmos. Chem. Phys., 11, 7755-7765, doi:10.5194/acp-11-7755-2011, 2011. 